\title{
SEATING COMFORT SATISFACTION LEVEL OF OFFICE WORKERS AND THEIR EXPECTATIONS FROM AN OFFICE CHAIR
} Münire Sibel ÇETIN*, The Graduate School of Natural and Applied Sciences, Dokuz Eylül University, Izmir, Turkey,
muniresibelcetin@gmail.com

(iD) https://orcid.org/0000-0003-1875-3302)

Gülseren KARABAY, Department of Textile Engineering, Dokuz Eylül University, Izmir, Turkey, gulseren.karabay@deu.edu.tr (iD) https://orcid.org/0000-0002-1231-2816)

Hasan ÖZTÜRK, Department of Mechanical Engineering, Dokuz Eylül University, Izmir, Turkey, hasan.ozturk@deu.edu.tr (iD) https://orcid.org/0000-0002-8308-8428)

Gülseren KURUMER, Department of Textile Engineering, Dokuz Eylül University, Izmir, Turkey, gulseren.kurumer@deu.edu.tr (iD) https://orcid.org/0000-0003-0062-3374)

Received: 13.10.2019, Accepted: 10.04 .2020 Research Article

*Corresponding author DOI: $10.22531 /$ muglajsci.632580

\begin{abstract}
Seating comfort is related with the individual's office chair features, user features and the time that is spent sitting on an office chair. The increase of the working hours at the offices leads to a variety of musculoskeletal disorders caused by the lack of improper workplace design and business equipment. The aim of this study is to investigate the discomfort complaints about the office chairs and the expectations of participants from an office chair and to determine the significate user and task features which affect the overall satisfaction from the office chair. This study is part of a continuing project, which seeks to design an office chair considering the discomforts and expectations in terms of structural design and textile design. Based on the results of the survey, an office chair which would is prospected to satisfy the expectations of the respondents will be designed. A survey was applied to randomly selected 382 respondents to determine the overall satisfaction level of respondents from their own current office chairs, the features of current their office chairs, the textile materials used on their office chair and their expectations from an office chair. It was found out that $74.89 \%$ of women and 58.05\% of men were not satisfied with their office chairs. $68.75 \%$ of the staff, who were not satisfied with their chairs, thought that their discomforts were caused by their office chairs. Besides, the results stated that textile materials used on office chair affect the comfortability of the chair and it is also determined that there are some expectations from the textile materials which have to be covered.

Keywords: Musculoskeletal disorders, Office Chair, Office Workers, Seating Comfort, Textile Materials

\section{OFIS ÇALIŞANLARININ OTURMA KONFORUNDAN MEMNUNIYET DERECELERİ VE BİR OFIS SANDALYESINDEN BEKLENTILERİ}

\section{Özet}

Oturma konforu; bireyin sandalyesinin özellikleri, kullanıcının özellikleri ve sandalyede oturularak geçirilen zamanla ilişsilidir. Ofiste çalışma saatlerinin artması, yanlış işyeri ve iş ekipmanı tasarımı; çeşitli kas-iskelet sistemi rahatsızlıklarına yol açmaktadır. Bu çalıșmanın amacı; katılımcıların bir ofis sandalyesinden beklentilerini belirlemek, ofis sandalyeleri ile ilgili rahatsızlıklarını araștırmak ve ofis sandalyesinden genel memnuniyeti etkileyen önemli iş ve kullanıcı özelliklerini tespit etmektir. Bu çalışma, yapısal tasarım ve tekstil tasarımı konusundaki rahatsızlık ve beklentileri göz önünde bulundurarak bir ofis sandalyesi tasarlamayı amaçlayan, devam etmekte olan bir projenin parçasıdır. Anket sonuçlarına göre, katılımcıların beklentilerini karşılaması beklenen bir ofis sandalyesi tasarlanacaktır. Rastgele seçilmiş 382 katılımcıya, kendi mevcut ofis sandalyelerinden genel memnuniyetlerini, sandalyelerinin sahip olduğu özellikleri, sandalyeleri üzerinde kullanılan tekstil malzemelerini ve bir ofis sandalyesinden beklentilerini belirlemek için bir anket uygulanmıştır. Kadınların \%74,89'unun ve erkeklerin \%58,05'inin ofis sandalyelerinden memnun olmadığı tespit edilmiştir. Sandalyelerinden memnun olmayan personelin \%68,75'i, rahatsızlıklarının ofis sandalyelerinden kaynaklandığını düşünmekteydi. Ayrıca, ofis sandalyesinde kullanılan tekstil malzemelerinin sandalyenin rahatlı̆̆ını etkilediği ve sandalyelere kaplanan tekstil malzemelerinden bazı beklentilerin olduğu tespit edilmiştir.

Anahtar Kelimeler: Kas İskelet Sistemi Rahatsızlıkları, Ofis Sandalyesi, Ofis Çalışanları, Oturma Konforu, Tekstil Malzemeleri

Cite

Çetin, M.S., Karabay, G., Öztürk, H., Kurumer, G., (2020). "Seating comfort satisfaction level of office workers and their 


\section{Introduction}

Seating comfort has been the focus of many researchers for many years. Recently, this issue has become even more significant for office workers due to long working hours. How we sit and what we sit on exert a load on the musculoskeletal and spinal structures. Sitting modes and seated features (e.g., components of chair design) have direct implication in raising or reducing spinal load and injury risks in sitting [1]. A comfortable seat should be adjustable and it should be satisfactory in terms of psychology since the sense of an unsatisfactory seat may cause the users to be distracted and unfocused on their work [2]. Increasing the availability, knowledge and use of adjustable chair functions and reducing barriers towards adjustment may help optimize the health and comfort of the office worker [3]. The users define seating comfort concerning their subjective experience [4] however; the researchers try to find a correlation between the seating comfort perception of users and objective measures of seating comfort. De Looze et al. [5] stated that pressure distribution was appeared to be the objective measure of subjective feelings of comfort or discomfort. Helander [6] linked sitting comfort and discomfort to different factors: while discomfort is related to biomechanics and fatigue factors, comfort is connected to a sense of well-being and aesthetics. As the sitting comfort is a subjective experience of the user, questioning the evaluation of his existing seat's ergonomic quality and his overall satisfaction from it, is a fundamental part of designing an office chair. An adequate office chair reduces the tension of the body and increases the physiological performance. However, comfortability of a person's office chair is not just enough to point for satisfaction. Aesthetics is the other point: if the user likes the appearance, the colour and the ambience, the user is apt to feel more comfortable. Appealing upholstery, which is neither too soft nor too stiff and distributes body pressure along the contact region, and at the same time, a breathable upholstery which lets heat and humidity escape, can strongly contribute to the feeling of comfort [5]. The softness of a seat is an important factor in reducing or preventing pain or discomfort [7]. The surface of the seat pan must support the weight of the upper body comfortably and securely. Hard surfaces generate pressure points that can be avoided by suitable upholstery, cushion or other surface materials that elastically or plastically adjust to body contours [8]. The feeling of comfort/discomfort while using a chair is strongly influenced by the heat exchange between the body and the furniture [9]. The surface material is essential for obtaining a comfortable seating. The distribution of temperature and humidity through various layers of textile material constructions of different seats is different [10]. Finally, it can be concluded that the textile materials, which are used on chairs, have a substantial role in sitting comfort inevitably.
There are many studies, which make an effort to improve user satisfaction considering ergonomics. In most of these studies, the office chairs were evaluated for their anthropometric designs. Different seats were compared to one another by considering their positive or negative effects on user's body instead of appraising the overall satisfaction level $[11,12,13,14,15]$. Besides, there are some papers in literature, in which survey results about the users' seating comfort, evaluation of a specific chair or comparison of different chair, were given $[2,15,16,17]$. At the end of all these studies, it can be said that seating comfort is the result of interaction among the features of the user, job and seat. Therefore, sitting comfort is a versatile issue and overall satisfaction of the user is the main crux of the subject [18].

In this study, survey participants were asked to evaluate their existing chairs and their effects on their bodies aggregately. Therefore, this survey involves different parts such as respondent's the overall satisfaction level from his office chair, his awareness of the discomforts that are caused by the chair, his expectations from an office chair. Besides, it aims to determine the effects of the textile materials, which are used on the surface of the chair in terms of comfort and ease of use. For that reason, this paper has extensive content and the results are the outputs of a survey, which was applied to a vast number of participants face to face. The aim of this paper is to provide important data through a survey to design an office chair.

\section{Materials and Methods}

Survey application method was used to collect the needed data for the design of the office chair. The questions were arranged in four parts: General information, information about health, chair properties and expectations. The closed-end and open-end questions and 7 points Likert scale were used in the questionnaire.

Reliability analysis was carried out to the results of a pilot study, which was applied to 30 participants. Demographic variables were encoded in binary form Yes / No so they were not included in reliability analysis. Cronbach alpha reliability coefficient of remaining variables was calculated. The questionnaire was considered statistically valid with an overall Cronbach alpha reliability coefficient of .842, which indicates that the questionnaire had acceptable reliability.

This survey was done from February to August of 2016 at Dokuz Eylül University, İzmir, Turkey. There are 6462 staff $(\mathrm{N})$ of which 3103 academics and 3359 administrative in the university and they are working sedentarily as a part of their job. The sample size was defined randomly and population proportion was estimated, at a $95 \%$ confidence interval and a margin of 
error of 0.5. 382 people of which 239 women and 143 men from different faculties of the university were surveyed face to face.

The below thirteen hypotheses were tested to determine the task and user features, which play a crucial role in the overall satisfaction from the office chair.

In the content of the survey, the below-given hypotheses were tested.

Hypotheses 1: There is a meaningful difference between sex and the individual's level of satisfaction from the chair.

Hypotheses 2: There is a significant difference between age and the individual's level of satisfaction from the chair.

Hypotheses 3: There is a meaningful difference between body height and the individual's level of satisfaction from the chair.

Hypotheses 4: There is a significant difference between body weight and the individual's level of satisfaction from the chair.

Hypotheses 5: There is a meaningful relationship between the individual's level of satisfaction from the chair and the educational status.

Hypotheses 6: There is a significant difference between the type of staff (Academic / Administrative) and the individual's level of satisfaction from the chair.

Hypotheses 7: There is a meaningful relationship between daily total sedentary working hours and the individual's level of satisfaction from the chair.

Hypotheses 8: There is a meaningful relationship between the duration of uninterrupted working sedentarily and the individual's level of satisfaction from the chair.

Hypotheses 9: There is a significant relationship between the duration of the break and the individual's level of satisfaction from the chair.

Hypotheses 10: There is a significant relationship between the period of using the chair and the individual's satisfaction level from the chair.

Hypotheses 11: There is a significant relationship between having muscle and skeletal problem and the individual's satisfaction level from the chair.

Hypotheses 12: There is a meaningful relationship between medication usage because of having muscle and skeletal problem and the individual's satisfaction level from the chair.

Hypotheses 13: There is a meaningful relationship between having numbness in certain regions of the body and individual's satisfaction level from the chair.

Shapiro-Wilk and Kolmogorov-Smirnov test statistics were used to determine the normality of the data. According to the results, the p-value was less than 0.05 so it cannot be said that these variables come from normal scattering masses. For this reason, nonparametric methods have been used to test the above hypotheses.

\section{Results and Discussion}

The satisfaction level of the participants was asked via 7 points Likert scales (1: extremely dissatisfied-7: extremely satisfied) questions. The responses between 1-4 were evaluated as unsatisfied and the ones between 5-7 were appraised as satisfied. 262 of 382 participants were unsatisfied. These participants declared that backrest, seat and the armrest were the first three parts of the office chair that cause discomfort. 224 of 382 participants indicated that they had musculoskeletal disorders. 154 of these 224 respondents stated that their office chair caused their musculoskeletal disorders in the related next question.

The results of the tested hypotheses were given in Table 1. The $p$ values of hypotheses below 0.05 means that that factor has an important role in the overall satisfaction from the office chair. According to Table 1, Hypotheses 1, 4, 7, 12 and 13 affect the overall satisfaction

Table 1. Statistics test results of hypotheses.

\begin{tabular}{ccc}
\hline Hypotheses & P-value & Statistics \\
\hline Hypotheses 1 & $\mathbf{0 . 0 0 0}$ & Chi-square \\
Hypotheses 2 & 0.208 & Mann-Whitney U \\
Hypotheses 3 & 0.418 & Mann-Whitney U \\
Hypotheses 4 & $\mathbf{0 . 0 2 4}$ & Mann-Whitney U \\
Hypotheses 5 & 0.332 & Chi-square \\
Hypotheses 6 & 0.417 & Chi-square \\
Hypotheses 7 & $\mathbf{0 . 0 3 4}$ & Chi-square \\
Hypotheses 8 & 0.233 & Chi-square \\
Hypotheses 9 & 0.064 & Chi-square \\
Hypotheses 10 & 0.300 & Chi-square \\
Hypotheses 11 & 0.131 & Chi-square \\
Hypotheses 12 & $\mathbf{0 . 0 5}$ & Chi-square \\
Hypotheses 13 & $\mathbf{0 . 0 0 0}$ & Chi-square
\end{tabular}

As an overall evaluation of the all hypotheses above, it was concluded that sex, body weight, having numbness on a certain part of the body and having a medical treatment due to musculoskeletal disorders were the user factors that affect the satisfaction level from the office chair. Total sedentarily working hours were the other factor that had a role in the satisfaction level from the office chair. Some physical features of the surface of the office chair can cause discomfort to people and this low comfort level can be the reason for the negative performance of the office workers. As another accepted hypothesis, the positive relationship between body 
weight and satisfaction level makes the selection of seat cushion important.

According to the results obtained from the research of Dhingra et al. (2003): the softness of a seat is an important factor in reducing or preventing pain or discomfort. The results of the survey in our study showed that, similar to the research of Dhingra et al. (2003), the physical properties of the materials used in the office chair may cause an increase or decrease in the comfort.

When the answers about the evaluation of the existing office chair's properties, given in Table 2, were examined, it was retained that over $90 \%$ of participants do not have separate neck support and separate backrest part and foot support. $29.06 \%$ of respondents were using a portable back or lumbar support on their office chair. According to survey results, it is concluded that separately designed neck support, backrest and waist parts would be better as structural design for the users. Thereby, they can adjust these parts singly in accordance with their bodies.

Table 2. Construction properties of office chairs.

\begin{tabular}{|c|c|c|c|c|}
\hline Questions about the current office chairs of respondents & Yes & $\%$ & No & $\%$ \\
\hline Does your office chair have armrest? & 368 & $96.34 \%$ & 14 & $3.66 \%$ \\
\hline Can the back of the chair fall back? & 362 & $94.76 \%$ & 20 & $5.24 \%$ \\
\hline Does your office chair have separate neck support? & 15 & $3.93 \%$ & 367 & $96.07 \%$ \\
\hline Is the waist support part of your chair separate from the back part? & 31 & $8.12 \%$ & 351 & $91.88 \%$ \\
\hline Do you have foot support mounted on your office chair? & 30 & $7.85 \%$ & 352 & $92.15 \%$ \\
\hline Do you use a portable back or lumbar support on your office chair? & 111 & $29.06 \%$ & 271 & $70.94 \%$ \\
\hline Is the height of your chair adjustable? & 353 & $92.41 \%$ & 29 & $7.59 \%$ \\
\hline Are your chair height and your table height match each other? & 277 & $72.51 \%$ & 105 & $27.49 \%$ \\
\hline Does your office chair rotate? & 369 & $96.60 \%$ & 13 & $3.40 \%$ \\
\hline Can your office chair's back be adjusted to forward and backwards? & 157 & $41.10 \%$ & 225 & $58.90 \%$ \\
\hline Can your office chair's back be adjusted to upward and downward? & 91 & $23.82 \%$ & 291 & $76.18 \%$ \\
\hline Does your office chair have wheels that allow the chair to move? & 157 & $41.10 \%$ & 225 & $58.90 \%$ \\
\hline Is it difficult to transport your chair? & 372 & $97.38 \%$ & 10 & $2.62 \%$ \\
\hline Is it user-friendly to adopt your office chair' s adjusting mechanisms? & 292 & $76.44 \%$ & 90 & $23.56 \%$ \\
\hline
\end{tabular}

Table 3. Evaluation of textile materials of office chairs.

\begin{tabular}{|c|c|c|c|c|}
\hline Evaluation of Textile Materials & Frequency & & $\begin{array}{c}\text { Evaluation of } \\
\text { Textile } \\
\text { Materials }\end{array}$ & Frequency \\
\hline Does your seating place make you sweat in hot weather? & 273 & 71.5 & 95 & 24.9 \\
\hline Is your seating place soft? & 257 & 67.3 & 125 & 32.7 \\
\hline Does your seat's upholstery material cause static electricity? & 142 & 37.2 & 240 & 62.8 \\
\hline Does the seat padding cause pain or any discomfort in the buttock? & 188 & 49.2 & 194 & 50.8 \\
\hline Does the seat backrest make you sweat in hot weather? & 268 & 70.2 & 114 & 29.8 \\
\hline Is your seat's upholstery easy to clean? & 237 & 62.0 & 145 & 38.0 \\
\hline Is there any fabric wear or damage on your seat? & 96 & 25.1 & 286 & 74.9 \\
\hline Is there any fabric fade on your seat upholstery? & 134 & 35.1 & 248 & 64.9 \\
\hline Did the form of your seat change over time? & 106 & 27.7 & 276 & 72.3 \\
\hline
\end{tabular}


As one of the results obtained from the research of Buell et al. (2014): A comfortable seat should be adjustable. In our study, parallel to the findings of Buell et al. (2014), It was concluded that the adjustable separate parts in the office chair were preferred by the users.

The other part of the survey was about the evaluation of textile material of the chair. The answers that were given in Table 3 revealed that the most important problems related to the textile materials of chairs were their causing sweating and discomfort to the buttock.

Table 4. Expectations of Respondents from an Office Chair.

\begin{tabular}{cc}
\hline $\begin{array}{c}\text { Expectations of Respondents from an Office } \\
\text { Chair }\end{array}$ & Frequency \\
\hline Back Support (can be adjusted up-down) & 325 \\
Neck Support (can be adjusted up-down) & 300 \\
Lumbar Support (can be adjusted up-down) & 298 \\
Breathable Fabric (Sweat Wicking) & 244 \\
Footrest (to come out under the chair and & 236 \\
foldable to the bottom when requested) &
\end{tabular}

Adjustable armrest (up-down, forwardbackwards, inward and outward, swivels, can be brought down)

$$
\begin{gathered}
\text { Stainless/ Easy to Clean Fabric } \\
\text { Massage Mechanism(Back) } \\
\text { Long-Lasting, Durable Materials }
\end{gathered}
$$

Fabrics made from natural materials such as cotton

Lumbar support that can move back and forth (to support the back cavity)

$$
\begin{gathered}
\text { Antistatic Fabric } \\
\text { Memory shape textile materials for seat } \\
\text { cushion } \\
\text { Softer Arm Rests (breathable fabric-covered } \\
\text { sponge) }
\end{gathered}
$$

\section{Antistatic Fabric}

User-friendly adjustment systems

Lightweight office chair

Softer cushion

Lockable wheels

Signal system for posture fatigues

At the end of the survey, the participants were asked to write their expectations from office chairs without a limitation. The most expected features could be seen in Table 4.

According to the responses of the open-ended questions, which stated the expectations of the respondents from an office chair, the respondents would prefer the fabrics, which were stainless/easy to clean, antistatic, made from natural materials and breathable as the upholstery.

De Looze. et al. (2003), the following comment was made in their research: A breathable upholstery can strongly contribute to the feeling of comfort. In our study, it was observed that users preferred breathable upholstery in the office chair, similar to the comments of De Looze et al (2003).

\section{Conclusion}

Seating comfort is one of the most important factors affecting the performance of the employees in the office environment. Apart from its influence on the posture and comfort, the poor ergonomics of a workplace may have a bad effect on job satisfaction. This reality brings out that people should use a good office chair.

The purpose of our research, which was attended by academic and administrative staff working at Dokuz Eylul University, was to determine whether the employees used a good office chair. Also, in our research, the features that users expect from an office chair were tried to be determined in order to feel comfortable.

According to the survey results, it is seen that most of the participants are not satisfied with their office chairs. The chair features, which the users are not satisfied, can be summarized as the inadequacy of the adjustment mechanisms of the construction, softness of the padding and upholstery materials and breathability.

Using the memory shape materials, which would take the form of the body, could be a solution to one of these problems. Besides the structural design, based on the expectations of respondents, adding a massage mechanism to the office chair might contribute to the relaxation of users.

Based on the finding of this research, different combinations of upholstery and padding materials could be examined for increasing the comfort features of an office chair. Finally, the role of aesthetics over the satisfaction levels and choosing the color of upholstery can be the subject of research for an attractive office chair design.

\section{Acknowledgment}

This study was completed as part of the first author's doctoral dissertation at Dokuz Eylul University the Graduate School of Natural and Applied Sciences. This work was supported by Dokuz Eylul University Department of Scientific Research Projects Funding (Project No.:2013.KB.FEN.36).

We thank to Olgun ALTAY, M.Sc. student of Mechatronics Engineering, for his assistance in the survey.

We thank to Dokuz Eylul University, Statistic, Risk and Actuary Applied Research Center (IRAMER) which 
contributed to the reliability analysis and evaluation of data of the survey.

\section{References}

[1] Nag, P. K., "Ergonomics of computer workstation, in office buildings", Springer, 149-181, 2019.

[2] Buell, J., Merchant, M., Oeser, M., Smith, J., Spilka, J., Wood, J. and Wydysh, J., "Descriptive analysis of seat ergonomics among Utica College population" Doctoral Dissertation, Utica College, Utica, New York, United States, 2014.

[3] Underwood, D., and Sims, R., "Do office workers adjust their chairs? End-user knowledge, use and barriers to chair adjustment", Applied Ergonomics, 77, 100-106, 2019.

[4] Runkle, V., "Benchmarking Seat Comfort", SAE Technical Paper 940217, 1994.

[5] De Looze, M. P., Kuijt-Evers, L.F. and Van Dieen, J. A. A. P., "Sitting comfort and discomfort and the relationships with objective measures", Ergonomics, 46(10), 985-997, 2003.

[6] Helander, M. G. and Zhang, L., "Field study of comfort and discomfort in sitting", Ergonomics 40(9), 895-915, 1997

[7] Dhingra, H. S., Tewari, V. K. and Singh, S., "Discomfort, pressure distribution and safety in operator's seat-a critical review", Agricultural Engineering International: the CIGR Journal of Scientific Research and Development, 5, 1-6, 2003.

[8] Zakaria, N. H., "Evaluation of the ergonomics checklist for office chair", Project Report, University of Tun Hussein Onn, 2015.

[9] Sales, R. B. C., Pereira, R. R., Aguilar, M. T. P., and Cardoso, A. V., "Thermal comfort of seats as visualized by infrared thermography", Applied Ergonomics, 62, 142-149, 2017.

[10] Vlaović, Z., Domljan, D., Župčić, I. and Grbac, I., "Thermal Comfort While Sitting on Office Chairs-
Subjective Evaluations", Drvna Industrija, 63(4), 263-270, 2012.

[11] Adu, G., Adu, S. and Effah, B., Frimpong-Mensah, K., Darkwa, N. A., "Office furniture design correlation of worker and chair dimensions", International Journal of Science and Research, 3(3), 709 - 715, 2014

[12] Mueller, G. F. and Hassenzahl, M., "Sitting comfort of ergonomic office chairs-developed versus intuitive evaluation", International Journal of Occupational Safety and Ergonomics, 16(3), 369374, 2010.

[13] Goossens, R. H. M., Netten, M. P. and Van der Doelen, B., "An office chair to influence the sitting behavior of office workers", Work 2012: A Journal of Prevention, Assessment, and Rehabilitation, 41, 2086-2088, 2012.

[14] Robertson, M., Amick III, B. C., DeRango, K., Rooney, T., Bazzani, L., Harrist, R. and Moore, A., "The effects of an office ergonomics training and chair intervention on worker knowledge, behavior and musculoskeletal risk", Applied Ergonomics, 40(1), 124-135, 2009.

[15] Hwang, S. C. and Choi, Y., "Modular design of a product to maximize customer satisfaction with respect to body size: A case study for designing office chair", International Journal of Precision Engineering and Manufacturing, 12(5), 791-796, 2011.

[16] Taifa, I. W. and Desai, D. A., "User requirements customization and attractive quality creation for design improvement attributes", International Journal for Quality Research, 11(1), 131-148, 2017.

[17] Askew, R. and Carlberg, S., "Office chairs in circular business models", Master of Science Thesis, KTH Royal Institute of Technology, Stockholm, Sweden, 2016.

[18] Pheasant, S. and Haslegrave, C. M., "Bodyspace: Anthropometry, Ergonomics, and the Design of Work", Taylor \& Francis, Florida, 2006. 